\author{
A.M. Rakhmetova ${ }^{1}$, Ye.G. Budeshov ${ }^{2}$, S.A. Shanin ${ }^{3}$ \\ ${ }^{1,2}$ Karaganda Economic University of Kazpotrebsoyuz, Kazakhstan \\ ${ }^{3}$ PLEKHANOV Russian University of Economics, Russia \\ aibota@mail.ru',yeraly_budeshov@mail.ru²,sershanin@rambler.ru ${ }^{3}$ \\ https://orcid.org/0000-0002-0008-48871, https://orcid.org/0000-0002-1676-2902², \\ https://orcid.org/0000-0003-2403-4005 \\ Scopus Author ID: $928767^{1}$, Scopus Author ID: $57199296110^{2}$, Scopus Author ID: $57189895928^{3}$
}

\title{
Development of education in the context of state management of the quality of life of the population in the Republic of Kazakhstan
}

\begin{abstract}
Object: This paper aims is to identify current trends and challenges to providing quality and affordable education to the population through the analysis of the process of state management of the quality of life in education, and to propose recommendations on how to resolve the said challenges and improve the quality of education in the Republic of Kazakhstan.

Methods: The following methods were used during the research: empirical, analytical, synthetic and comparativelogical ones.

Results: The article explores the education system of the Republic of Kazakhstan as a key branch of the social sector and the most important aspect in the state management of the quality of life of the country's population. In particular, we have seen into the indicators that characterize the following: coverage of children with preschool education, dynamics of secondary, technical and professional, higher and postgraduate education, inclusive education development, all of which are aimed at comprehensive development, creativity and strategic thinking, the ability to adapt to different personal conditions and contribute to improving the quality of life of the population, and consequently, sustainable socioeconomic development of the country.

Conclusions: As a result of the research, we have identified issues, the solution of which shall help to improve the quality of educational services and ensure their accessibility. We have formulated conclusions and proposals to improve the effectiveness of strategic management of the education system to achieve a decent level of quality of life for the population in the Republic of Kazakhstan. Recommendations formulated and proposed by the authors can be used by research centers involved in national research, by public associations and public administrations directly for the elaboration of state programs, strategic plans in education and in the process of improving the quality of education management system as a component of the quality of life of the Republic of Kazakhstan population as a whole.
\end{abstract}

Keywords: public administration, quality of life of the population, accessibility and quality of education, human capital, competitiveness.

\section{Introduction}

Economic literature views the quality of life of the population in the context of various aspects and interprets differently depending on the purpose of the study. Regardless of the conceptual solutions encountered, one of the essential and significant components of the quality of life is education; its accessibility and quality. In turn, the "quality of education" concept reflects the degree of compliance of the educational process at all levels and is characterized by real educational results that meet the established regulatory requirements, social and personal expectations of the population. Accordingly, ensuring access to quality education for as many people as possible shall also lead to an improvement in the quality of life of the population.

At the same time, there is a point of view circling in scientific community that says, education is presented as a secondary element of the "quality of life" category. We do not share this vision since in addition to its actual cost, education is also a means of achieving various results that have a creative value for the quality of human life. At the same time, while some of these results have monetary value and create income for an individual, others, such as self-realization and active cognitive activity, contribute to the expansion of human freedoms and potential opportunities, regardless of whether it currently has any impact on the individual's personal income and thus benefits both the individual and the entire society in achieving a decent future.

Certainly, given the significant impact of the availability and quality of education for society, an important task for public administration represented by government authorities at national and local levels is 
their participation in the formation of an appropriate institutional environment, adequate to the requirements of higher quality of life in its various aspects. This includes ensuring the elaboration of integrated development strategies of both companies and individual sectors associated with education.

The strategic documents developed by the state emphasize the importance of improving the level of education of the population and the effectiveness of the education system management. Thus, according to the Leader of the Nation N.A. Nazarbayev, the strategy "Kazakhstan-2050" indicates that "In order to become a developed and competitive nation we must become a highly educated nation. In the modern world simply embracing literacy is not enough. Our citizens must be ready to permanently gain new working skills using the most advanced equipment and the most modern production techniques." (Strategija "Kazahstan-2050" [Strategy "Kazakhstan-2050"], 2012).

According to the Strategic development plan of the Republic, the perspective positioning in education is presented as "the development of human capital with high-quality and demanded skills of the XXI century, which will determine the further growth of the economy of Kazakhstan. The education system should aim at ensuring accessibility and inclusiveness at all levels and training experts that meet both the labor market's current needs and the needs of the economy in the future." (Strategicheskij plan razvitija Respubliki Kazakhstan do 2025 goda [The strategic plan for development of the Republic of Kazakhstan until the year 2025], 2018).

Notably, the Global Competitiveness Index (hereinafter referred to as GCI) report of The World Economic Forum (hereinafter referred to as WEF) for 2019, puts Kazakhstan's competitiveness in the "Education and skills" factor on the 57th place, i.e. average level. Despite minor improvements in indicators such as "quality of vocational education" and "expected duration of education", the country's position in this rating is still low, which puts notable emphasis on the relevance of the topic of this research. In addition, the relevance is determined by the need to improve the mechanism of public administration in education. This shall provide the population with knowledge, skills and abilities that meet the requirements of a rapidly changing modern market economy and contribute to the successful adaptation of people to the new requirements of the labor market, their ability to withstand global challenges and shocks.

In this regard, the purpose of this study is to identify current trends and challenges to providing quality and affordable education to the population via the analysis of the state management of the quality of life in education, and to propose recommendations on how to resolve the said challenges and improve the quality of education in the Republic of Kazakhstan.

\section{Literature Review}

The following foreign and Russian researchers have studied and presented the issues of the influence of education on the quality of life of the population in their scientific works: C. E. Ross, M. Van Willigen, J.D. Edgerton, L.W. Roberts, S. von Below, J. V. Winters, P. Morais, V. L. Miguéis, A. S. Camanho, N.B. McLaren, M. A. Shorokhova, I. L. Sirotina and many others (C. E. Ross, M. Van Willigen, 1997; J.D. Edgerton et al., 2012; P. Morais et al., 2013; J. V. Winters, 2011; N. B. McLaren et al., 2015).

The analysis of author opinions given in scientific literature allows to classify them by similarity of education category definitions as a component of the quality of life of the population. For example, some authors argue that the demand for knowledge and high quality of education improves the quality of life of the population as it increases the possibility of access to interesting, permanent and paid work, increases the possibility of stable social relationships, especially marriage, which increase social support. It also develops analytical skills that people use to determine their behavior, to change personal preferences and restrictions / opportunities provided to individuals (C. E. Ross, M. Van Willigen, 1997; J. D. Edgerton et al., 2012).

A group of Russian scientists (N. B. McLaren, M. A. Shorokhova, I. L. Sirotina) take a different view and believe that a quality education is a relative concept associated with the socio-economic order of a particular society considering the stage of development and basic capacity as obtaining a quality education does not always guarantee the implementation of acquired knowledge in practice and high social status. This leads to the contradiction between the human desire to implement their knowledge and inability to do so. This can only be resolved by creating necessary conditions for the development of high-tech industries (N.B. McLaren et al., 2015).

In most studies, the quality of education is considered not only as a result of activity, but also as a process aimed at achieving the planned results considering the internal potential and external conditions of the object. At the same time, the assessment of the quality of education is the process of finding the degree of 
compliance of educational results and conditions for ensuring the educational process. In this regard, in addition to quantitative indicators of educational infrastructure, the assessment of the education quality is based on the number of the following quality indicators: universities' rankings in international indices, government costs on education, innovation development level, academic degree holders rate, competitiveness and professional mobility of students, relevance and competitiveness of graduates in the labor market, their achievements, etc.

Meanwhile, the quality of education is directly related to the availability of education, which is understood as the opportunity and equality for each participant in the educational process to get the desired quality educational resources. Depending on types of access to education, different social groups have different educational opportunities. In this regard, when solving problems of accessibility of education, the state focuses on socially vulnerable groups of the population with relatively limited opportunities to participate in the educational process. Managing access to education also includes creating educational needs, creating financial, infrastructure, and other opportunities (M. V. Novikov, 2012). The state and society need to focus on these very aspects in the framework of human development as a condition for achieving success, sustainable economic growth, prosperity and social well-being and improving the quality of life of the population (K. Birchler, K. Michaelowa, 2016; N. Ghaffarzadegan et al., 2017; R. Laurie et al., 2016; J. W. Lee, H. Lee, 2016; A. Nasibulina, 2017; D. M. Salvioni et al., 2017).

The concept that education is considered a factor of competitiveness of cities and the country as a whole achieved through increasing the number of qualified human resources, also deserves attention. For example, foreign authors argue that "The competitiveness of cities relies increasingly in their capacity to attract highly educated workers, as they are important assets for firms when choosing a location, and therefore the local level of human capital has a positive impact on the quality of life of the population" (Morais P. et al., 2013; Winters J. V., 2011). Human capital can be increased through education, professional training, gaining work experience. Time and money required for education and training can be considered an investment in human capital. This type of investment brings significant long-term and integral socio-economic effect in terms of volume by its nature. Therefore, it is the most beneficial one for the potential sustainable development of the modern innovative economy and the level of competitiveness of the country (A.A. Bulasheva, T.A. Kusainov, 2019; S. M. Dzhumasheva, 2018; G. Konop'janova et al., 2018).

We believe that the analysis and generalization of various points of view of the authors in the scientific literature in relation to the research topic do not allow us to consider the impact of education on the quality of life of the population narrowly and one-sidedly. Given that education is a part of quality of life, we must base the research of the existing problems and governance on an integrated approach that includes a number of the following criteria: education availability (based on the following indicators: number of public and private preschool education institutions, schools, colleges and universities, number of students and teachers in urban and rural areas, volume of state order for training, etc.), teaching staff structure (hereinafter referred to as TS) and its training level (based on the following indicators: skilled pedagogical personnel for preschool education, position in international rankings by subjects, academic degree holders rate, universities' positions in QS World University Rankings (foreign teachers' share, the ratio of teaching staff and the number of students, citation index, etc.)), the demand for graduates in the labor market (based on the following indicators: internationalization of the education system, command of English, the share of employed by the education level), etc.

\section{Methods}

In the course of the research, we used the following techniques and methods: empirical (collecting information), analytical (dividing the problem into homogeneous parts and considering them separately), synthetic (generalizing the conclusions made during the analysis), comparative-logical (comparing homogeneous elements in different situations, cross-country comparisons). The information base for the research consists of laws and regulations, research papers, monographs and publications by domestic and foreign scientists in public management of the quality of life of the population, and statistical collections on the education system of the Republic of Kazakhstan.

\section{Results}

We believe that the analysis of trends in education starts with the availability of education by monitoring a number of indicators of pre-school education such as the number of institutions, the number of students and teachers, capacity supply for students, etc. The State program for the development of education and science of the Republic of Kazakhstan for 2016-2019 (hereinafter referred to as the Program) approved by the 
government of the Republic of Kazakhstan dated July 24, 2018 No. 460 provides for and includes individual indicators of educational accessibility (Gosudarstvennaja programma razvitija obrazovanija i nauki Respubliki Kazakhstan na 2016-2019 gody [The state program of education and science development of the Republic of Kazakhstan for 2016-2019], 2018).

First of all, let us consider the dynamics of the development of the preschool education system's key indicators in the Republic of Kazakhstan over the past 5 years. For example, according to the results for the period of 2015-2019, there is an annual planned increase by 1480 units of the network of preschool organizations (see Table 1).

Table 1. Preschool education indicator trends in the Republic of Kazakhstan for the period of 2015-2019units

\begin{tabular}{|l|c|c|c|c|c|}
\hline \multicolumn{1}{|c|}{ Indicators } & 2015 & 2016 & 2017 & 2018 & 2019 \\
\hline Number of preschool institutions & 8834 & 9410 & 9828 & 10314 & 10583 \\
\hline urban area & 2844 & 3261 & 3672 & 4057 & - \\
\hline rural area & 5990 & 6149 & 6156 & 6257 & - \\
\hline state-owned property & 7059 & 7074 & 6770 & 6565 & 6284 \\
\hline private property & 1775 & 2336 & 3058 & 3749 & 4299 \\
\hline Number of students in preschool institutions & 758772 & 807170 & 862305 & 880896 & 893461 \\
\hline Capacity & 728551 & 757685 & 896985 & 832113 & - \\
\hline Capacity supply (students per 100) & 105,0 & 106,1 & 96,1 & 105,9 & - \\
\hline Number of teaching staff in preschool institutions & 80857 & 84796 & 90671 & 94838 & 97197 \\
\hline $\begin{array}{l}\text { Note- Compiled by the authors according to the data provided by the Ministry of National Economy of the Republic of Kazakh- } \\
\text { stan Statistics Committee on the basis of source data (Statisticheskie bjulleteni [Statistical Bulletins], 2020). } \\
\text { - reporting data for 2019 for certain indicators have not been published at the time of writing }\end{array}$ \\
\hline
\end{tabular}

Despite the fact that preschool education and training holds one of the most successful levels of education by the factor of involving the private sector in the network development (more than one third of preschool institutions are private (4299 units or $40.6 \%$ in 2019,1775 units or $20 \%$ in 2015, increase in preschool education coverage by $24.5 \%: 78.3 \%$ in $2019,77.0 \%$ in $2018,66.1 \%$ in $2017,64.5 \%$ in $2016,53.8 \%$ in 2015), there is still an issue with the lack of qualified teaching staff. This is due to low wages and high workload, which is reflected in the size of groups, the ratio of students and teachers (it remained unchanged over the past 5 years: 9 students per 1 employee). This indicates the insufficient effectiveness of the State Program in relation to quality indicators of the quality of preschool education(Gosudarstvennaja programma razvitija obrazovanija i nauki Respubliki Kazakhstan na 2016-2019 gody [The state program of education and science development of the Republic of Kazakhstan for 2016-2019], 2018). However, to improve the quality of education, regulations of the economic Commission for Europe (hereinafter referred to as the ECE) consider a smaller ratio of students and teachers to be more effective, because it allows staff to pay more attention to the needs of students individually and reduces the amount of time required to solve issues.

Now, to the secondary education. The number of secondary schools has decreased to 170 units during the study period ( 7563 for academic year 2014/2015, 7393 for academic year 2018/2019), and the number of private schools has increased by 78 units (189 in 2019; 111 in 2015) (see Table 2).

Table 2. Secondary education indicator trends in the Republic of Kazakhstan for the period of 2015-2019

\begin{tabular}{|c|c|c|c|c|c|}
\hline Indicators & $2014 / 2015$ & $2015 / 2016 * *$ & $2016 / 2017$ & $2017 / 2018$ & $2018 / 2019$ \\
\hline 1 & 2 & 3 & 4 & 5 & 6 \\
\hline \multicolumn{6}{|c|}{ Number of secondary schools, units } \\
\hline total & 7563 & 7511 & 7450 & 7414 & 7393 \\
\hline urban area & 1932 & 1965 & 1980 & 2012 & 2055 \\
\hline rural area & 5631 & 5546 & 5470 & 5402 & 5338 \\
\hline \multicolumn{6}{|c|}{ Number of students in general education schools, people } \\
\hline total & 2685063 & 2799585 & 2930583 & 3050770 & 3186234 \\
\hline urban area & 1403895 & 1481670 & 1567612 & 1650672 & 1757315 \\
\hline rural area & 1281168 & 1317915 & 1362971 & 1400098 & 1428919 \\
\hline \multicolumn{6}{|c|}{ Number of those who graduated from the main secondary school (grade 9) } \\
\hline total & 221907 & 224674 & 241188 & 230679 & 235404 \\
\hline urban area & 111032 & 110631 & 124244 & 119154 & 126619 \\
\hline rural area & 110875 & 114043 & 116944 & 111525 & 108785 \\
\hline
\end{tabular}


Development of education ...

\begin{tabular}{|c|c|c|c|c|c|}
\hline \multicolumn{6}{|l|}{ Continuation of Table 2} \\
\hline 1 & 2 & 3 & 4 & 5 & 6 \\
\hline \multicolumn{6}{|c|}{ Number of those who graduated from the main secondary school (grade 11) } \\
\hline total & 133309 & 129406 & 127369 & 127414 & 143089 \\
\hline urban area & 61721 & 61503 & 62102 & 63075 & 73061 \\
\hline rural area & 71588 & 67903 & 65267 & 64339 & 70028 \\
\hline left the country*** & - & - & - & 4158 & 7606 \\
\hline $\begin{array}{l}\text { Incl. those who entered } \\
\text { educational institutions }\end{array}$ & - & - & - & 3893 & 7117 \\
\hline \multicolumn{6}{|c|}{ Number of teaching staff in general education schools, people } \\
\hline total & 314591 & 325184 & 319167 & 334205 & 338755 \\
\hline \multicolumn{6}{|c|}{ Employed population with secondary vocational (special) education, people } \\
\hline total & 2794817 & 2987880 & 3201192 & 3466417 & 3701939 \\
\hline \multicolumn{6}{|c|}{$\begin{array}{l}\text { Note - Compiled by the authors according to the data provided by the Ministry of National Economy of the Republic of Kazakh- } \\
\text { stan Statistics Committee on the basis of source data (Statisticheskie bjulleteni [Statistical Bulletins], 2020). } \\
\text { * since 2014, statistical observation } 85-K \text { is excluded from the plan of statistical work for 2014, data is collected by the MES of } \\
\text { the Republic of Kazakhstan. } \\
\text { ** number of teaching staff in full-time public general education schools } \\
* * * \text { provided in the administrative form starting from } 2017 \text {. }\end{array}$} \\
\hline
\end{tabular}

One of the indicators reflecting the highly educated teachers is the results of PIRLS 2016, where Kazakhstan (by the factor of quality of reading and text comprehension by elementary school students) holds 27 th place (536 points) among 50 countries. This is comparable to Germany (537), Canada (543), Austria (541) and the Slovak Republic (535) and demonstrates the growth of the employed population with secondary vocational (special) education during the research period. In 2019, 4528 schools $(64.9 \%)$ were provided with conditions for inclusive education compared to 2015 (30\%), which is $30.4 \%$ higher.

However, despite the measures taken in the framework of the Program, the target figure has not yet been reached in terms of complete elimination of emergency and three-shift schools $(0.6 \%$ and $1.8 \%$, respectively), and therefore there is an overcrowding of schools and classes in metropolises and large cities. In particular, in 2019, there were 29 emergency and 122 three-shift schools (Gosudarstvennaja programma razvitija obrazovanija i nauki Respubliki Kazakhstan na 2016 - 2019 gody [The state program of education and science development of the Republic of Kazakhstan for 2016-2019], 2018).

Now to vocational educational and training (hereinafter referred to as VET). Its quantitative indicators also enjoy a growing trend. For example, during the research period, there was an increase in the number of colleges with a dual training introduced (518 in 2019, 348 in 2015) with the participation of more than 4000 companies. In addition, the share of training and production workshops, laboratories and state college special subject offices equipped with modern training equipment has significantly increased from $41.2 \%$ to $50 \%$, respectively. The project "Free VET for all" has been implemented since 2017 . According to it in 2019, reception by state order amounted to 94628 people. Over the past 4 years, the share of colleges that have created equal conditions and barrier free access for students with special educational needs (hereinafter referred to as SEN) has increased by $54.5 \%(69.5 \%$ in $2019,15 \%$ in 2015)(Gosudarstvennaja programma razvitija obrazovanija i nauki Respubliki Kazakhstan na 2016-2019 gody [The state program of education and science development of the Republic of Kazakhstan for 20162019], 2018). On the positive side, it should be noted that there is a system of preferential support for SEN students, which includes the following: free meals provision, dormitories and travel tickets provision, additional payments to scholarship allowances. At the same time, there is a shortage of qualified mentors, training masters. In some cases, there is an underdeveloped methodological and material-technical base, the backwardness of training systems from innovative technologies currently used in industrial production using innovative technologies and the latest technology (companies are forced to retrain workers in situ). As a result, there is a discrepancy in the content and quality of professional education to the employer requirements.

Speaking of higher and postgraduate education, $99 \%$ of higher education institutions (hereinafter referred to as HEIs) have been internationally accredited by agencies that are full members of the international European networks for ensuring the quality of education and are included in the register of the authorized education body. In comparison with the academic year 2016-2017, the number of foreign students in higher education has increased by 3 times by 27206 people (40043 in academic year 2019-2020) (Statisticheskie bjulleteni [Statistical Bulletins], 2020). Implementation of educational programs in Eng- 
lish continues. Over the past two years, 654 educational programs have been implemented. The number of teaching staff in English is 9270. Every year, the volume of the state order for the training of personnel in HEIs increases. In the academic year 2019-2020, the state order was 66556 (39700 in academic year 20162017). In particular, in 2019, the state order for the training of $\mathrm{PhD}$ and Master's degrees increased by 3.5 and 2 times making 2312 and 13159 (628 and 7429 in 2016), respectively (see Table 3).

Table 3. Higher and postgraduate education indicator trends in the Republic of Kazakhstan for the period of 2015-2019

\begin{tabular}{|c|c|c|c|c|c|c|c|c|c|c|}
\hline Indicators & \multicolumn{2}{|c|}{2015} & \multicolumn{2}{|c|}{2016} & \multicolumn{2}{|c|}{2017} & \multicolumn{2}{|c|}{2018} & \multicolumn{2}{|c|}{2019} \\
\hline \multicolumn{11}{|c|}{ Number of higher education institutions, units } \\
\hline total & \multicolumn{2}{|c|}{127} & \multicolumn{2}{|c|}{125} & \multicolumn{2}{|c|}{122} & \multicolumn{2}{|c|}{124} & \multicolumn{2}{|c|}{129} \\
\hline \multicolumn{11}{|c|}{ Number of teaching staff of higher educational institutions, people } \\
\hline total & \multicolumn{2}{|c|}{38087} & \multicolumn{2}{|c|}{38241} & \multicolumn{2}{|c|}{38212} & \multicolumn{2}{|c|}{38275} & \multicolumn{2}{|c|}{38500} \\
\hline \multicolumn{11}{|c|}{ Number of doctoral students, people } \\
\hline total & \multicolumn{2}{|c|}{2219} & \multicolumn{2}{|c|}{2710} & \multicolumn{2}{|c|}{3603} & \multicolumn{2}{|c|}{5609} & \multicolumn{2}{|c|}{6363} \\
\hline intake & \multicolumn{2}{|c|}{794} & \multicolumn{2}{|c|}{1086} & \multicolumn{2}{|c|}{1671} & \multicolumn{2}{|c|}{2766} & \multicolumn{2}{|c|}{1775} \\
\hline output & \multicolumn{2}{|c|}{533} & \multicolumn{2}{|c|}{619} & & 21 & & & & \\
\hline & & & & imber of & aster's stu & dents, peo & & & & \\
\hline total & & & & & & 609 & & & & \\
\hline intake & & & & 74 & & 829 & 21 & & & \\
\hline output & & & & & & 268 & 19 & & & \\
\hline & & & ber of st & lents of 1 & her educa & tional inst & itions, pec & & & \\
\hline total & 45 & & 477 & 074 & 496 & 209 & 542 & 158 & 602 & 300 \\
\hline intake & 11 & & 147 & 692 & 138 & 378 & 163 & 36 & $16 ?$ & 500 \\
\hline output & 14 & 84 & 138 & 004 & 127 & 084 & 130 & 691 & 142 & 400 \\
\hline & Emplo & d popula & n with hi & her and $\mathrm{i}$ & omplete $\mathrm{h}$ & gher and & stgraduat & educatic & people & \\
\hline total & 320 & 699 & 321 & 142 & 336 & 5990 & 348 & 576 & 342 & 471 \\
\hline & & & Exter & al outgoi & academic & mobility, & eople & & & \\
\hline total & & & & & & 10 & & & & \\
\hline & & & Exter & al incomi & academi & mobility & eople & & & \\
\hline total & & & & & & 12 & & & & \\
\hline & & $\begin{array}{l}\text { per of fo } \\
\text { e expen }\end{array}$ & $\begin{array}{l}\text { gn scient } \\
\text { f the sta }\end{array}$ & $\begin{array}{l}\text { ts attract } \\
\text { budget a }\end{array}$ & $\begin{array}{l}\text { to higher } \\
\text { extra-bu }\end{array}$ & $\begin{array}{l}\text { education } \\
\text { lgetary fu }\end{array}$ & $\begin{array}{l}\text { istitutions } \\
\text { s of unive }\end{array}$ & $\begin{array}{l}\text { f Kazak } \\
\text { sities, p }\end{array}$ & & \\
\hline total & & & & & & 38 & & & & \\
\hline & & Numb & and shar & of foreig & tudents in & higher ed & cation inst & utions & & \\
\hline 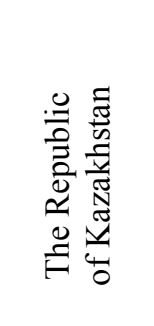 & 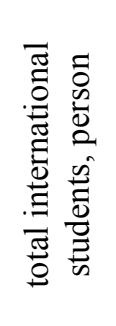 & 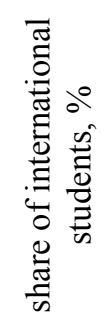 & 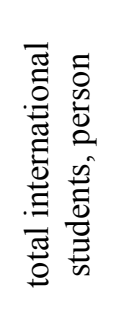 & 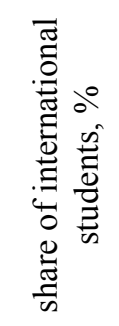 & 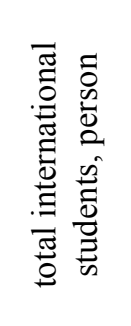 & 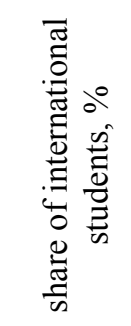 & 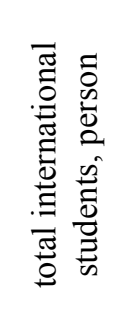 & 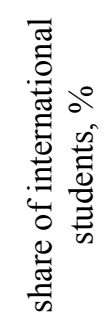 & 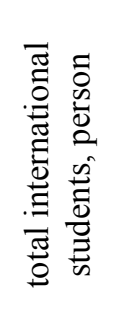 & 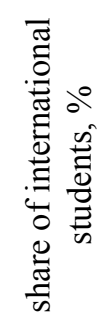 \\
\hline & 10829 & 2,4 & 12840 & 2,7 & 13898 & 2,8 & 21727 & 4,0 & 40043 & 6,6 \\
\hline
\end{tabular}

One of the important indicators allowing to assess the education system's quality, the potential for economic growth and competitiveness and the demand for young experts in the labor market, is the internationalization of the higher education system in Kazakhstan. It considers the needs of modern society, such as the ability to ensure academic mobility of students and teachers, training of staff of a new generation and qualification able to work in a globalized environment, which is reflected in international systems for assessing the competitiveness of universities and rating indicators of the quality of higher education. For example, the internationalization indicator analysis shows that the share of foreign students studying at universities in the Republic of Kazakhstan remains low (6.6\% in 2019), despite an increase in their number by 2 times during the research period. This indicator averaged $6 \%$ for the Organization for Economic Cooperation and Development (hereinafter referred to as the OECD) countries in 2017, where statistics are not divided into categories of "foreign students" and "international students" 
( $2.8 \%$ for Kazakhstan), but in about one third of the OECD countries it is equal to or exceeds $10 \%$. In higher education institutions in countries such as Australia, Austria, Luxembourg, New Zealand, Switzerland and the United Kingdom, the proportion of foreign students entering was at least $15 \%$, peaking at $47 \%$ for Luxembourg and $21 \%$ for Australia(OECD, 2019).

It is also necessary to consider changes in such indicators as the share of employed people by level of education and the number of employed people with vocational (special), higher and postgraduate education. Despite the positive dynamics of these indicators shown in Tables 2 and 3, which in 2019 amounted to $42.1 \%$ and $38.9 \%$ of total employment, respectively, the above indicators are 2 times lower than in the OECD countries, where the average employment rate is $82 \%$ for adults with a short-cycle higher education, and rising to $84 \%$ for those with a Bachelor's degree, $88 \%$ for Masters and $92 \%$ for Doctors of science or equivalent degrees. Young people with the highest qualifications (Master's and Doctorate or equivalent) usually have the best job prospects. In most countries, adults aged 25-34 with a Master's degree or equivalent qualification have a high employment rate: Denmark $-90 \%$, Iceland $-95 \%$, the Netherlands $-91 \%$, Norway $-94 \%$, Poland $-90 \%$. Young doctoral students also have good employment rates: the employment rate is $90 \%$ or higher in 16 of the 26 countries (Denmark - 96\%, Finland - 97\%, Lithuania $-99 \%$, Hungary - 96\%, Sweden - 93\%) (OECD, 2019).

We believe that the quality of education has a significant impact when students are forced to learn on their own. This provides the performance of self-education students, when high-quality teaching staff of the universities only gives direction and shows the methods that obtain the necessary knowledge. First of all, this requires having a sufficient number of highly educated quality staff of higher education institutions, so for the academic year 2018-2019 the country had: 2379 PhD Doctors, 3352 Doctors of Sciences, 12414 Candidates of Sciences (Analiticheskij otchet po realizacii principov Bolonskogo processa $\mathrm{v}$ Respublike Kazahstan [Analytical report on the implementation of the principles of the Bologna process in the Republic of Kazakhstan], 2019). The structure of the quality staff is dominated by the number of candidates of science, which is $31 \%$ of the total number of full-time teaching staff (table 4 ).

Table 4. Qualitative composition of university teaching staff and their academic degree holders rate, people/\%

\begin{tabular}{|l|c|c|c|c|c|c|c|c|}
\hline & \multicolumn{2}{|c|}{$\begin{array}{c}\text { Academic year } \\
2015-2016\end{array}$} & $\begin{array}{c}\text { Academic year 2016- } \\
2017\end{array}$ & \multicolumn{2}{c|}{$\begin{array}{c}\text { Academic year } \\
2017-2018\end{array}$} & \multicolumn{2}{c|}{$\begin{array}{c}\text { Academic year } \\
2018-2019\end{array}$} \\
\cline { 2 - 9 } & $\begin{array}{c}\text { No. of } \\
\text { people }\end{array}$ & $\begin{array}{c}\text { share, } \\
\%\end{array}$ & $\begin{array}{c}\text { No. of } \\
\text { people }\end{array}$ & $\begin{array}{c}\text { share, } \\
\%\end{array}$ & $\begin{array}{c}\text { No. of } \\
\text { people }\end{array}$ & $\begin{array}{c}\text { share, } \\
\%\end{array}$ & $\begin{array}{c}\text { No. of } \\
\text { people }\end{array}$ & $\begin{array}{c}\text { share, } \\
\%\end{array}$ \\
\hline Total TS & 38087 & 100 & 38241 & 100 & 38212 & 100 & 40594 & 100 \\
\hline Doctorsof Sciences & 3568 & 9,4 & 3499 & 9,2 & 3251 & 8,5 & 3352 & 8,3 \\
\hline Candidatesof Sciences & 14239 & 37,4 & 14023 & 36,7 & 13276 & 34,7 & 12414 & 30,6 \\
\hline PhD Doctors & 1272 & 3,4 & 1737 & 4,5 & 2062 & 5,5 & 2379 & 5,8 \\
\hline $\begin{array}{l}\text { Academic degree } \\
\text { holders rate }\end{array}$ & 19079 & 50,1 & 19259 & 50,4 & 18589 & 48,7 & 18145 & 44,7 \\
\hline
\end{tabular}

Note - Compiled by the authors based on the source data (Analiticheskij otchet po realizacii principov Bolonskogo processa $v$ Respublike Kazahstan [Analytical report on the implementation of the principles of the Bologna process in the Republic of Kazakhstan], 2019)

Despite the recorded growth of the high school teaching staff in the dynamics of recent years, the academic degree holders rate decreased by $5.4 \%$ in the academic year 2018-2019, and amounted to $44.7 \%$. This trend shows a decrease in the ability of higher and postgraduate education institutions to meet the growing needs of the country's population in obtaining quality educational services due to the low motivation of young scientists to improve their skills (low salary supplement for academic degrees), the outflow of qualified scientists to the practical sphere or outside the country in pursuit of a higher quality of life; the low status of a teacher and scientist in society due to negligibly low wages, low quality of life and excessive workload with routine tasks that have nothing to do with the scientific and educational process, which diverts a significant part of the time that can be used for self-education, publication of scientific articles and monographs.

We believe that the indicators of Kazakhstan universities in national and world rankings prove to be one most effective tool for ensuring the quality of training. International rankings become a tool for public and global assessment of educational institutions considering the quality of training, scientific potential of the institution, its contribution to the economic development of the country and society. In this regard, we feel important to note that the QS WUR-2020 rating includes 10 Kazakhstan universities. In comparison with 2017, the number of Kazakhstan universities presented in the rating has increased. Kazakh National 
Agrarian University (top “601+") and Buketov Karaganda State University (top "701+") have entered the rating for the first time (see Table 5).

Table 5. Positioning of Kazakhstan's universities in the QS World University Rankings for 2015-2019

\begin{tabular}{|l|c|c|c|c|c|}
\hline & 2015 & 2016 & 2017 & 2018 & 2019 \\
\hline Top 200+ & 1 & 1 & 1 & 1 & 1 \\
\hline Top 300+ & 1 & 1 & 1 & 3 & 0 \\
\hline Top 400+ & 0 & 1 & 2 & 0 & 2 \\
\hline Top 500+ & 1 & 1 & 2 & 3 & 1 \\
\hline Top 601+ & 1 & 2 & 1 & 2 & 4 \\
\hline Top 701+ & 5 & 2 & 8 & 10 & 10 \\
\hline Total universities & 9 & 8 & \multicolumn{5}{l|}{} \\
\hline
\end{tabular}

Among Kazakhstan's universities, Al-Farabi KNU takes the highest position: in 2015 the institution took 275th place and during the research period, improved its position in 2019 and took 207th place, effectively rising by 68 positions. However, despite the fact that Gumilyov ENU was in the top "300+" from 2015 to 2017, this university has lost 82 positions over the past two years to 418th place in 2019 (included in the top " $400+$ ").

\section{Discussion}

In the modern world, a necessary condition for the prosperity of a country that is a part of the world economy is a comprehensive state regulation of a complex multi-stage education system that includes significant targeted investments that contribute to the progressive and sustainable development of human potential as the basis of the national economy. At the same time, if the development of human capital is more of a social issue for the state, then for an individual, such development means, above all, increasing their competitiveness and efficiency, and, as a result, increasing opportunities to improve the quality of their life. This increase in the competitiveness of an individual is an important factor in the success of a nation and creates the most favorable basis for long-term sustainable economic growth (E. B. Ajmagambetov, 2018).

Certainly, within the framework of ensuring access to education in Kazakhstan, certain measures have been taken in recent years to increase the coverage of preschool education in order to prepare children for school and ensure the development of their skills. For example, in 2010, a "Balapan" Program launched for providing children with preschool education and training. It allowed doubling the coverage of preschool education. Today, the coverage of children aged 3-6 is $95.2 \%$, and this figure is planned to be increase to $100 \%$ by 2020 . However, the coverage of children aged $1-3$ with early childhood education remains low and amounted to $31.7 \%$ in 2018 as an issue of priority children in preschool of 446,2 thousand (2019) is still not resolved. Moreover, in large cities and growth points, the network of preschool education institutions does not sufficiently cover the existing need (Dobrovol'nyj Nacional'nyj obzor 2019 o realizacii povestki dnja do 2030 goda $\mathrm{v}$ oblasti ustojchivogo razvitija [2019 voluntary national review on the implementation of the 2030 sustainable development agenda], 2019). In turn, according to some experts, the shortage of supply in some cases leads to bureaucratic and corrupt cases of violation of official authority in order to resolve this issue on the principle of priority of the individual.

Despite the implementation of the Program in secondary education, the issue of overcrowding of classes and schools in large localities has not been resolved yet, and, as a result, the problem of two or three-shift training of schoolchildren exists. The pace of infrastructure renewal of the school network does not keep pace with the growth of child birth rates, migration processes, and the life of educational facilities. In the context of improving the quality of school education, worth mentioning is the impact of the costs of 12-year school education model, which diverts a substantial part of teacher time reducing its direct awareness and realization of individual approach to each student in accordance with their capacity and abilities, and implementation of a creative approach to the educational process itself.

The test system for evaluating intermediate and final sections of students' knowledge also raises a lot of questions from the point of view of the quality of secondary education. The lack of a complete and accurate scientific and empirical substantiation of the effectiveness of the new foreign model of 12-year schooling in Kazakhstan, which replaced the Soviet model of education formed within centuries and proven in the international community (a powerful brain drain in Soviet times) on the background of a gradual 
and multi-year transition (1980-2012 years, holding numerous interim assessments of the effectiveness of such transition) of the educational system of Great Britain to the Soviet model of education, raises a lot of questions as to whether the long-term and expensive reform of borrowing a foreign model is justified in the first place(Nazadvbudushhee: Anglija perehodit k sovetskoj sisteme obrazovanija [Backtothefuture: England moves to the Soviet education system], 2019). Do the authorities in this area aim to comply with the trends of integration and globalization processes in terms of the implementation of inter-country rating quantitative indicators?

The issue of the ratio of the quality of education in the regional context needs to be emphasized. The gap in the external evaluation of educational achievement (hereinafter referred to as the EEEA) indicators between urban and rural 9th grade students increased from 5.3 in 2016 to 8.1 points in 2019. The main reasons for the gap are the lack of qualified staff who do not want to work in conditions of poor quality of life in villages, the weak material and technical base of rural schools, poor quality and lack of access to internet in some cases. In this regard, the outflow of graduates from Kazakhstan schools to universities in the near and far abroad remains due to the declining quality of education in universities, the corruption component and weak career guidance of Kazakhstan universities and secondary education institutions, and most importantly, the lack of prospects for self-employment without protection in prestigious and highpaying jobs.

Along with the above mentioned bottlenecks of Kazakhstan's education sphere, we feel important to highlight VET's main issues, which include the weak logistical base of the colleges for technical professions and occupations; insufficient accommodation supply in VET hostels; VET graduates training level inconsistency with the employer requirements. Digitalization is one of the factors for increasing the availability of technical, professional and higher education in Kazakhstan. This creates the necessary conditions for promoting the concept of "lifelong learning" and equalizing the learning environment for students in remote, rural regions. Given the importance of digitalization of the educational process, $98.3 \%$ of the country's schools have access to the internet and more than 100000 subject teachers have underwent courses on the use of information and communication technologies. However, the territories of remote rural schools are still not covered with broadband internet. According to modern teaching methods, teachers in these schools are required to actively use information technologies.

One of the major issues limiting the increase in the global competitiveness of Kazakhstan's higher education is the teaching staff's low level of command of the English language. Only $6.8 \%$ of teachers of Kazakhstan universities can lecture in English(Gosudarstvennaja programma razvitija obrazovanija $\mathrm{i}$ nauki Respubliki Kazakhstan na 2016-2019 gody [The state program of education and science development of the Republic of Kazakhstan for 2016-2019], 2018), which reduces the degree of participation of teaching staff in such events as joint international research, publication of research results in foreign journals, cross-country cooperation, internships and training, their independent work on the search for foreign literature.

Thus, as a result of the analysis of modern trends in Kazakhstan's education sphere, we would like to note that state control of the quality of education and its impact on quality of life of the population in general requires a systematic approach, which in addition to the evaluation and monitoring also involves an assessment of the following qualitative indicators: the quality teacher staff, the demand for teaching staff and graduates in the labor market, etc. This approach should be based on the principle of receiving feedback from service recipients (student parents, school students, high school students, teachers, consumers and employers based on questionnaires, surveys, active work of independent public institutions and non-governmental bodies), which, in our opinion, could be the starting point for qualitative reform and improvement of not only the mechanism of state management of the education system, but also the quality of education itself as the basis for the reproduction of human capital, viability and future of the state.

\section{Conclusion}

As a result of the study of the education system of the Republic of Kazakhstan, we feel necessary to identify its weaknesses and strengths, and existing opportunities and threats using on the SWOT analysis method (table 6). 
Table 6. SWOT analysis of the education system of the Republic of Kazakhstan

\begin{tabular}{|c|c|}
\hline Strengths & Weaknesses \\
\hline $\begin{array}{l}\text { - positive student trends based on PIRLS results; } \\
\text { - increase in the volume of state orders for training } \\
\text { future experts; } \\
\text { - dual training development in VET sphere; } \\
\text { - } 99 \% \text { of Kazakhstan universities have internation- } \\
\text { al accreditation }\end{array}$ & $\begin{array}{l}\text { - insufficient number of qualified personnel in pre- } \\
\text { school education; } \\
\text { - incomplete coverage of students aged 1-3 in large } \\
\text { cities with early preschool education; } \\
\text { - low number of international students from the } \\
\text { world indicators perspective; } \\
\text { - low level of teaching staff's command of English } \\
\text { language; } \\
\text { - low pay for teaching staff; } \\
\text { - lack of conditions for scientific activity and sys- } \\
\text { tematic professional development of teaching staff; } \\
\text { - bureaucratic and corrupt component }\end{array}$ \\
\hline & \\
\hline $\begin{array}{l}\text { - increase of Kazakhstan universities participation } \\
\text { in international rankings; } \\
\text { - qualitative expansion of the academic mobility } \\
\text { program; } \\
\text { - salary increases and incentive bonuses for the } \\
\text { teaching staff; } \\
\text { - expansion of internal and foreign training pro- } \\
\text { grams for the teaching staff; } \\
\text { - computerization and giving access to the internet, } \\
\text { especially in rural localities; } \\
\text { - return of the Soviet education system elements to } \\
\text { secondary and higher education; } \\
\text { - digitalization development for accessibility of } \\
\text { education; } \\
\text { - construction of a network of comfortable schools } \\
\text { through construction in the framework of public- } \\
\text { private partnership (hereinafter referred to as PPP) }\end{array}$ & $\begin{array}{l}\text { - outflow of the population from the country, in- } \\
\text { cluding children and teenagers in the pursuit of bet- } \\
\text { ter education and subsequent employment without } \\
\text { protectorate; } \\
\text { - education degradation due to the reforms based } \\
\text { on blind copying of foreign systems, without ana- } \\
\text { lyzing and evaluating their effectiveness and re- } \\
\text { sults; } \\
\text { - competition from foreign universities, where tal- } \\
\text { ented Kazakhstan youth stay and work abroad after } \\
\text { graduating; } \\
\text { - decrease in the academic degree holders rate of } \\
\text { the qualitative composition of the teaching staff } \\
\text { against the background of the lack of material mo- } \\
\text { tivation and incentives for the latter }\end{array}$ \\
\hline
\end{tabular}

In conclusion, the authors propose a number of measures to solve current issues in the state management of the educational quality of life of the population:

- to create real working opportunities and conditions for training and motivational measures including: a new system of teacher training (professional training to maintain, broaden, deepen and improve previously acquired knowledge and skills through the use of modern innovative pedagogical technologies providing improvement of education quality); training using the updated content; an annual increase in the wages of teachers and educators by $25 \%$ (a mechanism for tangible indexation of income in accordance with the real inflation level); the widespread introduction of a labor rationing system for the teaching staff to improve the quality of their professional training and the implementation of creative opportunities;

- to reduce the gap in the education quality between urban and rural schools by taking comprehensive measures to provide with qualified teaching staff, to increase wages, to provide sufficient educational materials, internet, computer equipment and digital technology to rural schools;

- to build preschool institutions and general education schools at the expense of the state and the private sector using the PPP mechanism;

- reduce the teachers' workload by optimizing various forms of reporting and setting restrictions on engaging in non-standard functions and responsibilities not related to the educational process;

- to strengthen the practice orientation of the educational process in VET and higher education institutions by entering into academic calendars the mandatory and repeated practical classes directly at the produc- 
tion (businesses), inviting practitioners of relevant industries to conduct master classes in educational disciplines to master necessary practical skills of future young experts;

- to increase the availability of modern training equipment in VET with an annual increase of $25 \%$ in the share of training and production workshops to full complement;

- to consider the mechanism of motivation and material support for researchers (in the complex: pay, financing of research activities, systematic professional development and expansion of academic mobility programs for teaching staff);

- to raise the level of digitalization of education through wireless communications, cloud computing, microservers, computers and peripheral equipment, local networks, broadband internet access and other features that shall improve the quality at all levels of education and create conditions for the formation of competitive personality, increase literacy, and contribute to human capital development and access to education;

- to expand the range of educational programs in English, assist students and teaching staff in improving their language skills, develop appropriate infrastructure and conditions for the admission of foreign students to achieve the development of the internationalization level in higher and postgraduate education and further bringing the national education system closer to international standards.

We believe that implementation of the proposed measures and suggestions to increase the availability and improve the quality of the education system in the context of the system (complex) approach shall allow creation of the appropriate institutional environment with a positive influence on expanding the capacity and possibilities of all subjects of scientific and educational process, their implementation in professional and personal growth, shall help to establish social trust in society, to develop society with active civil participation, to strengthen the rule of law, which in turn, shall ensure the progressive and sustainable economic growth of Kazakhstan.

\section{References}

Ajmagambetov E.B. (2018). Reshat' nuzhno soobshha (You need to decide together). Kazahstanskaja pravda (Kazakhstan truth), 220, 5

Analiticheskij otchet po realizacii principov Bolonskogo processa v Respublike Kazahstan [Analytical report on the implementation of the principles of the Bologna process in the Republic of Kazakhstan]. (2019). Centr Bolonskogo processa i akademicheskoj mobil'nosti MON RK [Center of the Bologna process and academic mobility MES RK], 40. Retrieved from https://enic-kazakhstan.kz/ru/analitika/otchety-1

Birchler K., Michaelowa K. (2016). Making aid work for education in developing countries: An analysis of aid effectiveness for primary education coverage and quality. International Journal of Educational Development, 48, 37-52. https://doi.org/10.1016/j.ijedudev.2015.11.008

Bulasheva A.A., Kusainov T.A. (2019). Ocenka vlijanija investicij v obrazovanie na razvitie chelovecheskogo kapitala i ego vozdejstvie na jekonomicheskij rost (Impact assessment of investments in education on the development of human capital and its influence on the economic growth). Vestnik Karagandinskogo universiteta. Serija "Jekonomika" (Bulletin of the Karaganda university. "Economy series"), 1(93), 41-48

Dobrovol'nyj nacional'nyj obzor 2019 o realizacii povestki dnja do 2030 goda v oblasti ustojchivogo razvitija [2019 voluntary national review on the implementation of the 2030 sustainable development agenda]. (2019). AO "Institut jekonomicheskih issledovanij", Nur-Sultan [Institute of Economic Research JSC, Nur-Sultan], 40-47. Retrieved from https://www.un.org/sustainabledevelopment/ru/education/

Dzhumasheva S.M. (2018). Sovremennye modeli upravlenija kachestvom obrazovatel'nyh uslug v vuzah (Modern models of managing quality of educational services in universities). Vestnik Karagandinskogo universiteta. Serija "Jekonomika" (Bulletin of the Karaganda university. "Economy series"), 3(91), 72-78

Edgerton J.D., Roberts L.W., von Below S. (2012) Education and Quality of Life. In: Land K., Michalos A., Sirgy M. (eds) Handbook of Social Indicators and Quality of Life Research. Springer, Dordrecht, 265-296

Ghaffarzadegan N., Larson R., Hawley J. (2017). Education as a Complex System. Systems Research and Behavioral Science, 34, 211-215. https://doi.org/10.1002/sres.2405

Gosudarstvennaja programma razvitija obrazovanija i nauki Respubliki Kazahstan na 2016-2019 gody [The state program of education and science development of the Republic of Kazakhstan for 2016-2019]. 2018. Postanovlenie Pravitel'stva Respubliki Kazahstan ot 24 ijulja 2018 goda № 460 [Decree of the Government of the Republic of Kazakhstan No. 460 dated July 24, 2018]. Retrieved from http://adilet.zan.kz/rus/docs/P1800000460

Konop'janova G., Bajkenov Zh., Brauvajler K. (2018). Analiz pokazatelej dostupnosti vysshego obrazovanija v Kazahstane (Analysis of indexes of Kazakhstan higher education accessibility). Vestnik Karagandinskogo universiteta. Serija “Jekonomika” (Bulletin of the Karaganda university. "Economy series"), 2(90), 139-144 
Laurie R., Nonoyama-Tarumi Y., Mckeown R., Hopkins C. (2016). Contributions of Education for Sustainable Development (ESD) to Quality Education: A Synthesis of Research. Journal of Education for Sustainable Development, 10(2), 226-242. https://doi.org/10.1177/0973408216661442

Lee J. W., Lee H. (2016). Human capital in the long run. Journal of Development Economics, 122, $147-169$. https://doi.org/10.1016/j.jdeveco.2016.05.006

Maklaren N. B., Shorohova M. A., Sirotina I. L. (2015). Kachestvo zhizni i kachestvo obrazovanija: problema sootnoshenija (Quality of life and quality of education: the problem of correlation).Integracija obrazovanija (Integration of Education), vol. 19, 4, 72-77

Morais P., Migueis V. L., Camanho A. S. (2013). Quality of Life Experienced by Human Capital: An Assessment of European Cities. Social Indicators Research, 110(1), 187-206. https://doi.org/10.1007/s11205-011-9923-5

Nasibulina A. (2017). Education for sustainable development. In Advances in Intelligent Systems and Computing, vol. 498, 947-954. https://doi.org/10.1007/978-3-319-42070-7_87

Nazad v budushhee: Anglija perehodit k sovetskoj sisteme obrazovanija [Back to the future: England moves to the Soviet education system]. 2019. Novye Izvestija [Recent News]. Retrieved fromhttps://newizv.ru/news/society/19-012019/nazad-v-buduschee-angliya-perehodit-k-sovetskoy-sisteme-obrazovaniya

Novikov M. V. (2012). Ocenka dostupnosti obrazovanija (Education accessibility assessment). Otechestvennaja i zarubezhnaja pedagogika (Domestic and foreign pedagogy), 2 (5), 11-14.

OECD (2019), Education at a Glance 2019: OECD Indicators, OECD Publishing, Paris, https://doi.org/10.1787/f8d7880d-en.

QS World University Rankings 2020 Yearbook. (2020). QS Quacquarelli Symonds Limited, $1{ }^{\text {st }}$ edition, 21-45

Ross C. E., Van Willigen M. (1997). Education and the Subjective Quality of Life. Journal of Health and Social Behavior, 38(3), 275-297. https://doi.org/10.2307/2955371

Salvioni D. M., Franzoni S., Cassano R. (2017). Sustainability in the higher education system: An opportunity to improve quality and image. Sustainability (Switzerland), 9(6), 914. https://doi.org/10.3390/su9060914

Statisticheskie bjulleteni [Statistical Bulletins]. (2020). Komitet po statistike Ministerstva nacional'noj jekonomiki Respubliki Kazahstan [Ministry of National Economy of the Republic of Kazakhstan Statistics committee].Retrieved from https://www.stat.gov.kz/official/industry/62/statistic/5

Strategija "Kazahstan-2050" Novyj politicheskij kurs sostojavshegosja gosudarstva. ["Strategy Kazakhstan-2050": new political course of the established state"]. 2012. Poslanie Prezidenta Respubliki Kazahstan - Lidera nacii N.A. Nazarbaeva Narodu Kazahstana [Address by the President of the Republic of Kazakhstan, Leader of the Nation, N.Nazarbayev]. Retrieved from http://adilet.zan.kz/rus/docs/K1200002050

Strategicheskij plan razvitija Respubliki Kazahstan do 2025 goda [The strategic plan for development of the Republic of Kazakhstan until the year 2025]. 2018. Ukaz Prezidenta Respubliki Kazahstan № 636 ot 15 fevralja 2018 goda [Decree of the President of the Republic of Kazakhstan No. 636 dated February 15, 2018]. Retrieved from https://www.akorda.kz/ru/official_documents/strategies_and_programs

Winters J. V. (2011). Human capital, higher education institutions, and quality of life. Regional Science and Urban Economics, 41(5), 446-454. https://enic-kazakhstan.kz/ru/analitika/otchety-1.

\section{А.М. Рахметова, Е.Г. Будешов, С.А. Шанин}

\section{Қазақстан Республикасындағы халықтың тұрмыс сапасын мемлекеттік басқарудың мән мәтінінде білім беру саласының дамуы}

\section{Аңдатnа}

Maқ̧саты: Зерттеудің мақсаты білім беру саласындағы халықтың тұрмыс сапасын мемлекеттік басқару үдерісін талдау арқылы қалыптасқан үрдістерді анықтап, халыққа сапалы және қолжетімді білім беруді тежеуші мәселелерді айқындау, сонымен қоса оларды шешуге және Қазақстан Республикасындағы сапалы білім беруді арттыруға бағытталған ұсыныстарды жасау.

Әдісі: Зерттеу жүргізу барысында келесідей әдістер қолданылған: эмпирикалық, талдау, синтетикалық және салыстырмалы-логикалық.

Kорытынды: Мақалада елдегі халықтың тұрмыс сапасын мемлекеттік басқарудағы маңызды аспектісі және әлеуметтік саланың кілтті тарауы ретіндегі Қазақстан Республикасының білім беру жүйесіне талдау жүргізілген. Атап айтқанда кешенді түрде жан-жақты дамуға, шығармашылық пен стратегиялық ойлауға, тұлғаның әртүрлі жағдайларға бейімделе алуына бағытталған және халықтың тұрмыс сапасын жоғарылатуға, демек елдің тұрақты әлеуметтік-экономикалық дамуына мүмкіндік туғызатын: балаларды мектепке дейінгі білім берумен қамтуды, орта, техникалық және кәсіптік, жоғары және жоғары оқу орнынан кейінгі білім беру, инклюзивті білім берудің даму динамикасын сипаттайтын көрсеткіштер қарастырылған.

Тұжырымдама: Зерттеу нәтижесінде білім беру қызметтерінің сапасын жақсартуға септігін тигізетін және халыққа олардың қолжетімділігін қамтамасыз ететін негізгі мәселелер анықталған. Қорытындылай келе, Қазақстан Республикасындағы халықтың тұрмыс сапасының лайықты деңгейіне қол жеткізу үшін білім беру жүйесін стратегиялық басқарудың тиімділігін арттыру бойынша қорытындылар мен ұсыныстар тұжырымдалған. Авторлармен тұжырымдалып көрсетілген ұсыныстарды тікелей мемлекеттік басқару 
органдарымен және қоғамдық бірлестіктермен, жалпы мемлекеттік зерттеулермен айналысатын ғылымизерттеу орталықтарымен білім беру саласындағы мемлекеттік бағдарламаларды, стратегиялық жоспарларды әзірлеу барысында, сондай-ақ жалпы Қазақстан Республикасы халқының тұрмыс сапасының құраушысы ретінде білім беру сапасының басқару жүйесін жетілдіру үдерісінде қолдануға болады.

Кілm сөздер: мемлекеттік басқару, халықтың тұрмыс сапасы, білім беру сапасы және қолжетімділігі, адами капитал, бәсекеге қабілеттілік.

\section{А.М. Рахметова, Е.Г. Будешов, С.А. Шанин}

\section{Развитие образовательной сферы в контексте государственного управления качеством жизни населения в Республике Казахстан}

\section{Аннотация}

Цель: Целью настоящего исследования являются посредством анализа процесса государственного управления качеством жизни населения в сфере образования определение сложившейся тенденции и выявление проблемы, ограничивающей предоставление качественного и доступного образования населению, а также предложение рекомендаций, направленных на их решение и повышение качества образования в Республике Казахстан.

Memodbl: При проведении исследования были использованы следующие методы: эмпирический, аналитический, синтетический и сравнительно-логический.

Результаты: В статье проведен анализ системы образования Республики Казахстан как ключевой отрасли социальной сферы и важнейшего аспекта в государственном управлении качеством жизни населения страны. В частности, рассмотрены показатели, характеризующие охват детей дошкольным образованием, динамику развития среднего, технического и профессионального, высшего и послевузовского образования, инклюзивного образования, которые в комплексе нацелены на разностороннее развитие, на кретивность и стратегическое мышление, на умение адаптироваться к разным условиям личности и способствуют повышению качества жизни населения, а следовательно, и устойчивому социально-экономическому развитию страны.

Bblводы: В результате исследования выявлены проблемы, решение которых поможет улучшить качество образовательных услуг и обеспечить их доступность для населения. В заключении сформулированы выводы и предложения по повышению эффективности стратегического управления системой образования для достижения достойного уровня качества жизни населения в Республике Казахстан. Рекомендации, сформулированные и предложенные авторами, могут быть использованы научно-исследовательскими центрами, занимающимися общегосударственными исследованиями, общественными объединениями, и, непосредственно, органами государственного управления при разработке государственных программ, стратегических планов в сфере образования, а также в процессе совершенствования системы управления качества образования как составляющей качества жизни населения Республики Казахстан в целом.

Ключевые слова: государственное управление, качество жизни населения, доступность и качество образования, человеческий капитал, конкурентоспособность.

\section{References}

Birchler K. Making aid work for education in developing countries: An analysis of aid effectiveness for primary education coverage and quality $[$ Текст] / K. Birchler, K. Michaelowa // International Journal of Educational Development. - 2016. - № 48. - C. 37-52.

Edgerton J.D. Education and Quality of Life [Текст] / J.D. Edgerton, L.W. Roberts, S. von Below // Handbook of Social Indicators and Quality of Life Research. Springer, Dordrecht. — 2012. — C. 265-296.

Ghaffarzadegan N. Education as a Complex System [Текст] / N. Ghaffarzadegan, R. Larson, J. Hawley // Systems Research and Behavioral Science. — 2017. — № 34. - C. 211-215.

Laurie R. Contributions of Education for Sustainable Development (ESD) to Quality Education: A Synthesis of Research [Текст] / R. Laurie, Y. Nonoyama-Tarumi, R. Mckeown, C. Hopkins // Journal of Education for Sustainable Development. — 2016. — № 10(2). — C. 226-242.

Lee J.W. Human capital in the long run $[$ Текст] / J.W. Lee, H. Lee // Journal of Development Economics. — 2016. — № 122. - C. 147-169.

Morais P. Quality of Life Experienced by Human Capital: An Assessment of European Cities [Tекст] / P. Morais, V.L. Migueis, A.S. Camanho // Social Indicators Research. — 2013. — № 110(1). — C. 187-206.

Nasibulina A. Education for sustainable development [Текст] / A. Nasibulina // In Advances in Intelligent Systems and Computing. - 2017. - Vol. 498. - C. 947-954.

OECD (2019), Education at a Glance 2019: OECD Indicators, OECD Publishing, Paris, https://doi.org/10.1787/f8d7880d-en.

QS World University Rankings 2020 Yearbook. (2020). QS Quacquarelli Symonds Limited, $1^{\text {st }}$ edition, 21-45. 
Ross C.E. Education and the Subjective Quality of Life [Текст] / C.E. Ross, M. Van Willigen // Journal of Health and Social Behavior. — 1997. — № 38(3). - C. 275-297.

Salvioni D.M. Sustainability in the higher education system: An opportunity to improve quality and image [Tекст] / D.M. Salvioni, S. Franzoni, R. Cassano // Sustainability (Switzerland). — 2017. — № 9(6). — C. 914.

Winters J.V. Human capital, higher education institutions, and quality of life [Текст] / J.V. Winters // Regional Science and Urban Economics. — 2011. — № 41(5). - C. 446-454.

Аймагамбетов Е.Б. Решать нужно сообща. Мониторинг [Текст] / Е.Б. Аймагамбетов // Казахстанская правда. 2018. - № 220. - С. 5.

АО «Институт экономических исследований», Нур-Султан. Добровольный национальный обзор 2019 г. о реализации повестки дня до 2030 года в области устойчивого развития. — 2019. — С. 40-47. — (https://www.un.org/sustainabledevelopment/ru/education/).

Булашева А.А. Оценка влияния инвестиций в образование на развитие человеческого капитала и его воздействие на экономический рост [Текст] / А.А. Булашева, Т.А. Кусаинов // Вестн. Караганд. ун-та. Сер. Экономика. - 2019. — № 1(93). - С. 41-48.

Джумашева С.M. Современные модели управления качеством образовательных услуг в вузах [Текст] / С.М. Джумашева // Вестн. Караганд. ун-та. Сер. Экономика. — 2018. — № 3(91). — С. 72-78.

Комитет по статистике Министерства национальной экономики Республики Казахстан: Стат. бюлл. (https://www.stat.gov.kz/official/industry/62/statistic/5).

Конопьянова Г. Анализ показателей доступности высшего образования в Казахстане [Текст] / Г. Конопьянова, Ж. Байкенов, К. Браувайлер // Вестн. Караганд. ун-та. Сер. Экономика. — 2018. — № 2(90). — С.139-144.

Макларен Н.Б. Качество жизни и качество образования: проблема соотношения [Текст] / Н.Б. Макларен, М.А. Шорохова, И.Л. Сиротина // Интеграция образования. — 2015. - Т. 19, № 4. — С. 72-77.

Новиков М.В. Оценка доступности образования [Текст] / М.В. Новиков // Отечественная и зарубежная педагогика. - 2012. - № 2 (5). - С. 11-14.

Новые Известия. Назад в будущее: Англия переходит к советской системе образования. - 2019. (https://newizv.ru/news/society/19-01-2019/nazad-v-buduschee-angliya-perehodit-k-sovetskoy-sisteme-obrazovaniya).

Послание Президента Республики Казахстан - Лидера нации Н.А. Назарбаева народу Казахстана. Стратегия «Казахстан-2050»: Новый политический курс состоявшегося государства. (http://adilet.zan.kz/rus/docs/K1200002050).

Постановление Правительства Республики Казахстан от 24 июля 2018 года № 460. Государственная программа развития образования и науки Республики Казахстан на 2016-2019 годы. (http://adilet.zan.kz/rus/docs/P1800000460).

Указ Президента Республики Казахстан № 636 от 15 февраля 2018 года. Стратегический план развития Республики Казахстан до 2025 года. — (https://www.akorda.kz/ru/official_documents/strategies_and_programs)

Центр Болонского процесса и академической мобильности МОН РК. Аналитический отчет по реализации принципов Болонского процесса в Республике Казахстан. — 40 c. — (https://enic-kazakhstan.kz/ru/analitika /otchety$1)$. 